https://doi.org/10.52240/1857-2367.2020.2(21).50

\title{
PARTICULARITĂȚILE ÎNMULȚIRII VEGETATIVE ALE UNOR SPECII DE SEMPERVIVUM L.
}

\author{
Irina SFECL $\breve{A}$ \\ Grădina Botanică Națională (Institut) „Al. Ciubotaru”, \\ Chişinău, Republica Moldova
}

\begin{abstract}
This article includes results of the research on the peculiarities of the vegetative propagation of five species of Sempervivum L., namely: Sempervivum arenarium W. D. J. Koeh.; S. arachnoideum L.; S. grandiflorum Haw.; S. montanum L. and S. tectorum L. The period during which the species begins to develop stolons has been determined. The data on the vegetative propagation coefficient, obtained and calculated statistically, are given below. S. arachnoideum has proven to be the most prolific species.
\end{abstract}

Key words: Sempervivum L., vegetative propagation coefficient.

Înmulţirea reprezintă funcția biologică comună tuturor organismelor vii de a se reproduce. Cunoașterea mecanismului înmulțirii la plantele cultivate şi a factorilor care îl favorizează sau îl inhibă permit dirijarea lui în scopuri practice. În condiții naturale, multe specii de plante au proprietatea de a se înmulţi vegetativ. La unele specii această proprietate, formată în procesul evoluției, asigură înmulțirea și răspândirea. În această lucrare este reliefat rezultatul cercetării înmulțirii vegetative a cinci specii de nevăstuică precum: Sempervivum arenarium W. D. J. Koeh.; S. arachnoideum L.; S. grandiflorum Haw.; S. montanum L. și S. tectorum L.

Sempervivum L. (nevăstuică, urechelniță) este un gen al familiei Crassulaceae. Acesta cuprinde circa 40 de specii de plante perene de până la $35 \mathrm{~cm}$ înălțime, sempervirescente, suculente, pubescente, monocarpice, ce dezvoltă stoloni. Frunzele cărnoase, ovoide sau alungite, cu vârf ascuțit, lucioase sau mate, pubescente cu peri glandulari, rareori glabre, pe margini ciliate, cele bazale dispuse în rozete, cele tulpinale alterne. Rozete dense de $1-15 \mathrm{~cm}$ în diametru. Tija florală pubescentă, erectă, neramificată. Inflorescența corimbiformă. Flori hermafrodite, actinomorfe. Fruct foliculă alungită (Lord 2003; Ardelean 2011; Sava 2013).

Genul Sempervivum este răspândit din Maroc până în Iran, Turcia, în partea de nordest a deșertului Sahara și Caucaz, munții Iberiei, Alpi, Carpați și Lanțul muntos al Balcanilor. Vegetează în fisurile stâncăriilor (Lord 2003; Pînzaru 2020). În flora spontană a Republicii Moldova este cunoscut doar Sempervivum ruthenicum Schnittsp. \& C. B. Lehm., specie periclitată (EN), inclusă în Cartea Roșie a Republicii Moldova (2001, 2015), cultivată ex-situ în Grădina Botanică Națională (Institut) "Alexandru Ciubotaru" (GBNI) (Izverscaia, Ghendov, Șabanova 2015). Pe lângă specia menționată, în colecția 
Laboratorului plante ornamentale al GBNI, sunt cultivaţi alți 16 taxoni de nevăstuică.

Taxonii specifici de Sempervivum sunt plante decorative prin floare și habitus. Formează decoruri minunate în aranjamentele de stâncării și în combinații cu alte plante. Poate fi plantată pe ziduri, în ghivece sau ca plantă de bordură. Avantajele utilizării acestor plante constă în faptul că nu au concurență în realizarea efectului estetic pe suprafețe, uneori, foarte mici și sunt rezistente la condițiile nefavorabile ale mediului (ger, secetă, sol sărac, insolație puternică ș.a.).

Nevăstuica poate fi multiplicată atât generativ cât și vegetativ. Înmulțirea practicată şi cu rezultate mai bune constă în separarea stolonilor de planta mamă. Numărul rozetelor nou formate variază de la specie la specie. Acest fapt a servit ca argument pentru stabilirea coeficientului de multiplicare vegetativă caracteristică speciei. În luna mai a fost plantat materialul biologic al celor cinci specii menționate de nevăstuică în celule alveolare cu diametrul de $15 \mathrm{~cm}$ în substrat de cultură în amestec cu nisip (1:1). Pentru fiecare specie au fost selectate cel puțin 10 rozete uniforme.

Coeficientul înmulțirii vegetative reprezintă numărul de indivizi noi apăruți (în cazul speciilor studiate - stoloni). Acest indice depinde de unii factori interni și externi, precum: proprietățile biologice ale speciei, condițiile meteorologice ale anului și agrotehnica de cultivare. Unii autori afirmă că plantele de Sempervivum formează rozete fiice (stoloni) doar când au realizat o mărime caracteristică fiecărei specii în parte (Zaharia 2007). Dezvoltarea stolonilor a fost evidențiată mai întâi la $S$. arachnoideum, la 38 de zile de la plantare, urmat de: $S$. tectorum - 46 de zile; S. arenarium - 48 de zile; S. montanum - 56 de zile și $S$. grandiflorum - 78 de zile de la plantare.

Sistematizarea datelor și stabilirea coeficientului de multiplicare vegetativă $(\mathrm{Cmv})$, la speciile studiate de Sempervivum, a fost realizată la 5 luni de la plantare (octombrie). Din datele obținute și calculate statistic, putem remarca că toate speciile experimentate au dezvoltat stoloni, însă doar $S$. arachnoideum a prezentat urmași de ordinul 1 și 2. Analizând rezultatele obținute se atestă o variabilitate a $(\mathrm{Cmv})$ atât între specii, cât și în cadrul aceleiași specii. Variabilitatea în cadrul speciei este redată de valoarea minimă și maximă înregistrată, după cum urmează: S. arenarium - 0-3; S. arachnoideum - 2-11; S. grandiflorum - 0-1; S. montanum - 1-4 și S. tectorum - 1-4. Coeficientul de multiplicare vegetativă (Cmv) stabilit are următoarele valori: S. arenarium - 1,30 $\pm 0,396 ; S$. arachnoideum $-5,50 \pm 1,035 ; S$. grandiflorum $-0,33 \pm 0,167 ; S$. montanum $-2,25 \pm 0,167$ și S. tectorum $-2,27 \pm 0,506$. Cu toate că prezintă o variabilitate pronunțată a capacității de formare a stolonilor de la individ la individ, coeficientul multiplicării vegetative caracteristic speciei $S$. arachnoideum este net superior celorlalte specii testate.

Cercetările au fost realizate în cadrul proiectului 20.80009.7007.14 „, Cercetări privind mobilizarea diversității vegetale cu potențial ornamental pentru conservarea ex-situ”.

\section{BIBLIOGRAFIE SELECTIVĂ}

1. Ardelean A. Enciclopedia plantelor decorative, Vol. II, 2011,Editura ALL, București, p. 206-208

2. Izverscaia T., Ghendov V., Şabanova G., Sempervivum ruthenicum Schnittsp. et C.B. Lehm, În: Cartea Roșie a Republicii Moldova, ed. a 3-a, 2015, Editura Știința, p. 62.

3. Lord T., Flora The gardener's bible, Vol 1, 2003, Ed. „Cassell” London, p. 1332-1334. 